\title{
Beliefs About Learning A New Language After 45 Years Old
}

Sila Ay*

\begin{abstract}
In Turkey, where life expectancy increases steadily, a very small amount of elder people are attending foreign language learning courses. In order to have a better understanding, this study focuses on the question whether beliefs of people from different age groups are effective in this manner. To examine the different age groups' beliefs, an online questionnaire was conducted. While deciding on the statements of the questionnaire, popular assumptions and Turkish cultural beliefs were taken into consideration. The findings revealed that although participants find some languages harder to learn they believe that attitude plays a major role in language learning and it is easier to learn a new language for a person who has already learnt one. Most of the participants believe that, learning a new language may prevent dementia and Alzheimer's disease. The results show that, people from different ages think in favour of learning a new language after 45-years-old.
\end{abstract}

Keywords: Beliefs, Adult Language Learning, Older Adults, Lifelong Language Learning.

\section{Yaşından Sonra Yeni Bir Dil Öğrenmeye İlişkin İnanışlar}

Ortalama yaşam süresinin hizla artmakta olduğu Türkiye'de erişkin yaş grubunda olup - bu çalışma kapsaminda 45 yaş ve üzeri kişiler-yeni bir dil öğrenmeye başlayan öğrencilerin sayısı genç ögrencilere oranla oldukça azdır. Bu çalışma, söz konusu durumun halkın inanışlarından mı kaynaklandığını araştırmak amacıyla farklı yaş gruplarından insanlarm konuya ilişkin görüşlerini, inanışlarını sormuştur. Araştırmanın veri toplama aracı olarak kullanılan çevrimiçi sormacanın maddeleri, Türk kültürüne ve yaygın varsayımlarına dayandırılmıştır. Araştırmanın sonuçları, katılımcıların bazı dilleri öğrenmenin daha zor olduğu ve tutumun dil öğrenmede önemli bir yer tuttuğunu düşündükleri ve daha önce en az bir yabancı dil öğrenmiş olan kişilerin yeni bir dil ögrenmelerinin daha kolay olduğuna inandıkların göstermektedir. Katılımcıların büyük çoğunluğunun yeni bir dil öğrenmenin bunamayı ve Alzheimer hastalı̆̆ını engelleyeceğini düşündükleri de görülmektedir. Çalışmaya katılan farklı yaş gruplarından katılımcılar, 45 yaşından sonra yeni bir dil öğrenmeye başlanabileceği ve başarılı olunabileceği görüşündedirler.

Anahtar kelimeler: İnanış, Erişkin Yabancı Dil Öğrencisi, İleri Yaş, Yaşam Boyu Öğrenme.

* $\quad$ Yrd. Doç. Dr., Ankara Üniversitesi, Dil ve Tarih-Coğrafya Fakültesi. 


\section{Introduction}

For a very long time, following the younger the better idea, foreign language learning studies have focused mainly on young language learners. However, with the latest increase in life expectancy and notions like third age, the concept of lifelong learning improved steadily. This concept suggests a more holistic look at the design and process of foreign language teaching. In 1985, life expectancy was 17 years shorter in Turkey (61.3 years) than in Japan (78.3 years) but the expectancy increased in all Organization for Economic Co-operation and Development (OECD) countries between 1985 and 2010. Although the largest increase was in Turkey (11.8 years) by 2010, life expectancy was highest ( 82.7 years) in Japan and still lowest (73.1 years) in Turkey (Zare, Gaskin \& Anderson, 2015: 1). According to statistics, in 2015, life expectancy in Turkey is 78 years, 80.7 years for females and 75.3 for males. As seen in Table 1, almost half of the Turkish population is between 25-54 years old and the third age group is only $15 \%$ of the population.

Table 1: Distribution of the population according to age and gender in Turkey (http://www.indexmundi.com/turkey/age_structure.html, 2014)

\begin{tabular}{|l|l|}
\hline Age & Percentage / Gender Population \\
\hline 0 -14 years & $25.5 \%$ (male 10,660,110 / female 10,179,850) \\
\hline $15-24$ years & $16.8 \%$ (male 6,989,099 / female 6,709,480) \\
\hline $25-54$ years & $42.9 \%$ (male $17,650,790 /$ female $17,358,730)$ \\
\hline $55-64$ years & $8.1 \%$ (male 3,289,605 / female 3,291,199) \\
\hline 65 years and over & $6.7 \%$ (male 2,517,219 / female 2,973,310) \\
\hline
\end{tabular}

In Turkey, the official language is Turkish and since 1950s English as a foreign language is a compulsory subject in schools. Some private schools teach other languages as elective foreign language courses as well. Especially in big cities, languages like German, French, Italian, Spanish, Japanese, Russian, Arabic, Chinese, Korean, Persian and Greek are also learned in language institutes by a considerable amount of people. One of the long-established language institutes is Ankara University's Language Teaching Centre (TÖMER). In this institute a wide range of students learn foreign languages and receive language passports which are valid by Common European Framework of Reference for Languages. 
As mentioned above, Turkey's third age population is low and people are usually reluctant to start learning a new language. This study will be addressing the lifelong language learning issue by focusing on the question whether beliefs of people from different age groups are effective in this manner or not. In order to have a preunderstanding of the age profile of learners, TÖMER's records between 2010 and 2015 were viewed. This review revealed that, the number of foreign language students enrolled in TÖMER between 2010 and 2015 was 86122 . And as seen in Figure 1, only $5 \%$ of these students were 45 years and up.

Figure 1: Number of foreign language students enrolled in TÖMER between 2010 and 2015

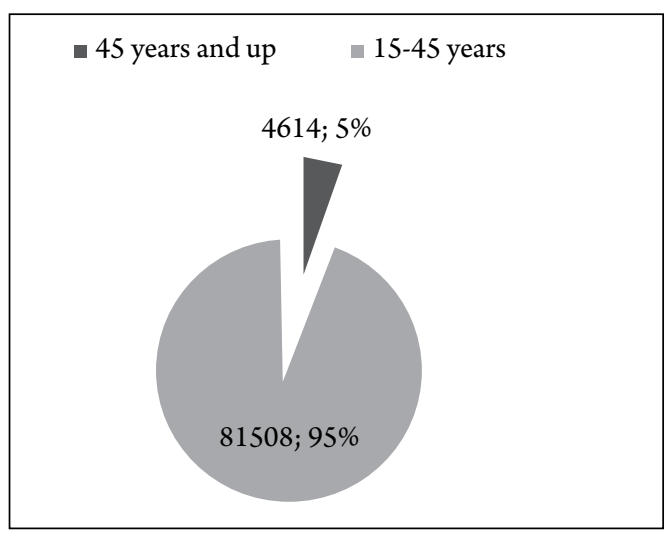

In TÖMER's records, the language classes are grouped as English, German, French, Italian, Spanish, Arabic, Japanese, Russian and Other. The "other" category consists of Chinese, Korean, Persian and Greek. As seen in Figure 2, although English is a compulsory subject and they all have already studied it, people who are 45 and up still have a tendency to attend English classes which means they are not starting to learn a new language but renewing their knowledge or upgrading their skills. On the other hand, languages like Arabic, Japanese and Russian who have a different writing system from Turkish are also popular with this group of learners. So it can be assumed that, although elder people are reluctant to start learning a new language, if they decide to do so, it does not matter if the language is typologically close to their first language or have the same writing system with it or not. 
Figure 2: Distribution of enrolment numbers of students who are 45 years and up in TÖMER between 2010 and 2015

\begin{tabular}{|c|c|c|c|c|c|c|c|c|c|c|}
\hline & & & & tudents & who are & 45 year & and $u_{I}$ & & & \\
\hline $\bar{v}$ & 500 & & & & & & & & & \\
\hline 5 & 400 & & & & & & & & & \\
\hline 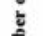 & 300 & & & & & & & & & \\
\hline 言 & $\begin{array}{l}200 \\
100\end{array}$ & & & & & & & & & \\
\hline & 0 & & i. & rin & & i 1 & 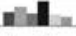 & & I & \\
\hline & & English & German & French & Italian & Spanish & Arabic & Japanese & Russian & Other \\
\hline & - 2010 & 454 & 42 & 59 & 27 & 57 & 46 & 8 & 77 & 167 \\
\hline & $=2011$ & 564 & 82 & 36 & 4 & 78 & 65 & 1 & 116 & 212 \\
\hline & $=2012$ & 491 & 34 & 57 & 11 & 76 & 43 & 2 & 40 & 181 \\
\hline & - 2013 & 227 & 20 & 76 & 18 & 61 & 84 & & 45 & 168 \\
\hline & $=2014$ & 181 & 9 & 22 & 4 & 27 & 39 & 6 & 35 & 120 \\
\hline & $=2015$ & 200 & 19 & 14 & 8 & 25 & 30 & 8 & 14 & \\
\hline & & & & & & Langu & & & & \\
\hline
\end{tabular}

\section{Age factor in language learning}

It was assumed that, adult learners were incapable of learning a foreign language as successful as young learners or not at all (Penfield \& Roberts, 1959), but nowadays researchers acknowledge that the language learning device remains intact, adult learners can benefit from their experiences, they have an increased brain development and have a more complex cognitive processing (Schleppegrell, 1987; Singleton \& Lengyel, 1995).

It has been discussed whether there is a biologically based critical period and an agerelated decline in the success of foreign language learning that prevents adult learners from achieving nativelike competence (Bailey, Bruer, Symons, \& Lichtman, 2001). The critical period hypothesis was proposed in 1959 by Penfield and Roberts and it was followed up by Lenneberg in 1967. Many studies using behavioural evidence confirmed this hypothesis (Johnson, 1992; Johnson \& Newport, 1989; Oyama, 1976; Patkowski, 1980, 1994). Although these studies used different types of measurements to test the proficiency, the general result was that, proficiency declined in relation to age of initial exposure to the foreign language. For example, Johnson and Newport $(1989,1991)$ have argued that, there is a strong age-related decline in proficiency for languages learned prior to puberty and variation in achievement among individuals who are exposed to a second language later in life. Some researchers (e.g., Epstein, Flynn, \& Martohardjono, 1996; Hakuta, 2001) on the other hand, proposed that, language learning potential is fundamentally changed after a critical period apart from the initial exposure fact. 
There has been little consensus between the supporters of critical period hypothesis, about what age constitutes the critical point. Researchers have various claims, for the age at which the critical period terminates. For instance, it is claimed to be 5 years (Krashen, 1973), 6 years (Pinker, 1994), 12 years (Lenneberg, 1967), or 15 years (Johnson \& Newport, 1989) in different studies. An alternative to the critical period hypothesis is that learning a foreign language gets harder with age, mostly because of factors, that are not specific to language but social and educational variables that influence learning potential and opportunity, as well as cognitive aging. Among these social factors, education has the main effect. Flege, Yeni-Komshian and Liu have reported complex effects of educational programs and in one of their studies, the effects of age on learning disappeared when education was controlled (Flege, Yeni-Komshian \& Liu, 1999).

Another factor is: the changes in cognition that occur with aging. Kemper (1992) pointed out that older adults' second language proficiency could be affected by such factors as working memory capacity, cognitive processing speed, and attention. According to Paradis (2004: 59), the critical period hypothesis applies to implicit linguistic competence. The decline of procedural memory for language, forces late second language learners to rely on explicit learning, which results in the use of a cognitive system different from that which supports the first language. The acquisition of implicit competence is affected biologically and cognitively. That, the plasticity of the procedural memory for language gradually decreases after about age 5 and reliance on conscious declarative memory increases from about age 7 (Paradis, 2004). This hypothesis is further supported by studies on exceptionally successful adult learners (Skehan, 1998; Ioup, Boustagui, Tigi, \& Moselle, 1994). Paradis (2004) also indicates that, later learners compensate by relying more heavily on metalinguistic knowledge and pragmatics.

\subsection{Adult learners}

There are great variations in how people are affected by ageing processes, which is why adults represent the most heterogeneous group within the population. Although people are similar at birth, throughout life, factors like geographical environment, culture, education and health, contribute to this heterogeneity. Seventy-year-olds can be found in need of constant care in a nursing home, while many 80 -year-olds still live active, independent lives and report high levels of well-being (Monstad, 2006). Here comes the notion of the third age, which was associated with British social philosopher and historian Peter Laslett, who argues that there is a new generation of retired people who finds itself in a position of greater 
potential agency. According to this new generation, retirement offers the opportunity to develop a distinct and personally fulfilling lifestyle unconnected with the contingencies of working life (Laslett, 1989).

There are physical and cognitive changes in the older students by aging. Most common physical changes are altered eye sight and declined hearing. But these changes can be easily overcome by using some special teaching techniques and materials. While trying to cope with these physical changes, mental functions may not change at all or may show a decline. Attention, basic communication skills, visual understanding, comprehending discourse may stay stable, but selective attention, verbal fluency, complex visual skills, naming of objects, learning complex new tasks and foreign languages often show some decline (Cohen, 2003). On the other hand, some researchers agree that disease, rather than age, seems to alter cognitive skills. Also, societal beliefs about lacking cognitive functioning among older adults may influence their own expectation and belief in the ability for optimal cognitive functioning (Daatland \& Solem, 2000, op.cit. Monstad, 2006). Adults are faster to produce foreign language words from their first language translations (Chen \& Leung, 1989), and they can adopt a learning strategy that makes more use of first language information when compared to children. Also they usually use their first language in the early stages of learning, even at the level of learning basic lexical information. As demonstrated in some examples (e.g. Brown, Kane \& Long, 1989), strategies developed in one learning scenario are often generalized.

\subsection{Older adult learning}

Edward Thorndike and John Dewey made important contributions in the field of older adult learning. Thorndike claimed that older adults had great potential for acquiring new knowledge and that the societal belief in a lack of learning abilityled to a low self-confidence. He also acknowledged that, learning competed with other necessary activities such as work, sport, family life, and sleep (Gibbons, 2003). Besides, Dewey valued interaction, reflection and past experience, and saw learning as a lifelong activity (1986).

There are many subfields like geronto education, geragogy, educational gerontology, instructional gerontology, andragogy, elder learning, lifelong learning (Brookfield, 1995; Knowles, Holton III\& Swanson,2014; Withnall, 2002) within adult and older adult learning. Malcolm Knowles proposed a new label and a new technology of adult learning (1968: 351), which he defined as the art and science of helping adults learn. In late $20^{\text {th }}$ century, with the concept of lifelong learning, andragogy grew in an attempt to distinguish learning approaches and methods that are more effective for adults. The need to understand 
the relevance of learning something new is particularly important in motivating the learner. For example, in the last decade, the assumption that, learning something new every day would prevent dementia and Alzheimer's disease, works as a major motive in starting to learn a new language among the older population. Although many adult learners of a foreign language end up with lower than nativelike levels of proficiency, most of these learners fail to engage in the task with sufficient motivation, commitment of time or energy. Support from their environments, especially from their families and associates is very important in the process. Successful adults usually invest sufficient time and attention in learning a new language and they benefit from high motivation. Age does influence language learning, but primarily because it is associated with social, psychological, educational, and other factors that can affect foreign language proficiency, not because of any critical period that limits the possibility of language learning by adults (Marinova-Todd, Marshall \& Snow, 2000: 27-28)

\section{Aims and scope of the study}

To examine the different age groups' beliefs about the language students who are beyond the age of 45 , an online questionnaire was administered to 380 Turkish participants. The questionnaire, was created using the Kwik Survey host and it was originally in Turkish. The online questionnaire began on March 4, 2016 and ended on March 11, 2016. In the first 24 hours it reached 200 participants. An invitation to take the questionnaire was sent to associates through Facebook and by email invitations. In Facebook messages along with a link to the online questionnaire, the participants received a request to pass the link to their associates, family and friends. These second order of invitations expanded the respond numbers very quickly. After the participants had completed the questionnaire, data was presented in a downloadable format on Kwik Survey, which was further analysed in Excel. The research questions of the study are as follows:

(1) What beliefs do people from different ages have about language learning in general and adult language learning in particular?

(2) Is there a correlation between the beliefs and language course enrolment percentages?

\section{Participants}

380 participants responded the questionnaire. 189 of them were female and 186 male, 5 of the participants did not indicate their gender. 12 different age-groups (in 5 years range) were identified in order to analyse the data of the first question (see Figure 3 ). With 55 participants, the largest age-group was the group of 41-45-year-olds. Whereas the smallest age-group was the group of 66-70-year-olds with 15 participants. 
Figure 3: Age groups and gender distribution of participants

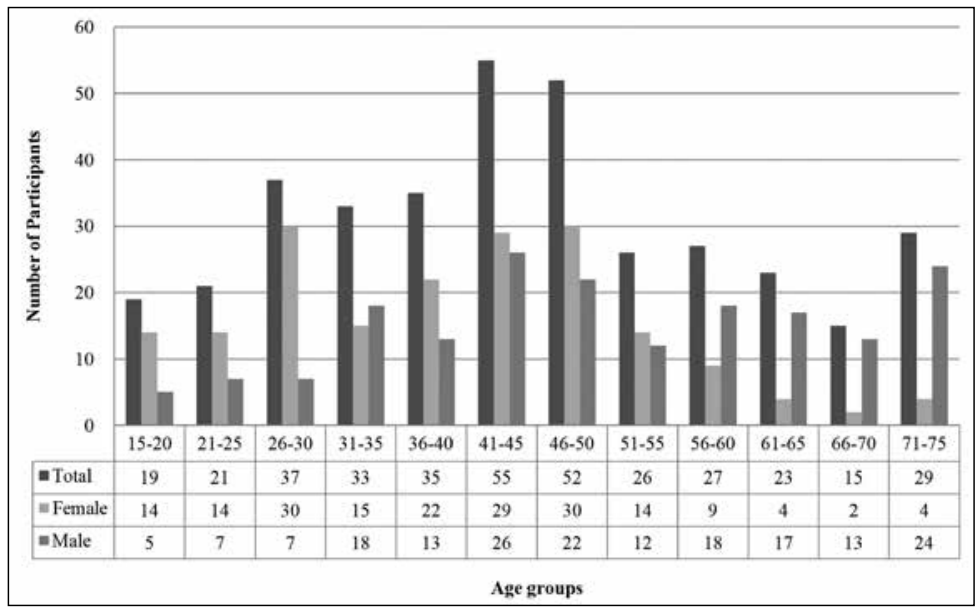

41 of the participants were high school students and/or graduates, 193 of them had bachelor's degree, 88 participants had master's degree and 42 of them had a doctorate degree.

The participants stated that, they knew a variety of foreign languages. As mentioned above, English is a compulsory subject in schools, so the majority (334 of the participants) knew it as a foreign language. French, German, Italian, Spanish, Russian, Arabic, Japanese and Chinese were also listed as foreign languages known. 39 of the participants stated that, they knew other languages too (see Figure 4).

\section{Questionnaire}

The questionnaire consisted of 8 statements and 3 questions about language learning and adult language learning. While deciding on the statements of the questionnaire, popular assumptions and Turkish cultural beliefs were taken into consideration. For example, critical period hypothesis is seen as a fact, without any doubt, for people who are not educated in the fields of Linguistics or Language Teaching, so it is not usually questioned at all. Also, the public belief about some languages being harder than others is very common, without considering the typological features. Although current methods of language teaching are being used nowadays, especially between 1950-1980 Grammar Translation Method was used in Turkish Public schools. That is why there is still a dominance of explicit grammar teaching in most of the learning environments. 
Figure 4: Foreign languages known by participants

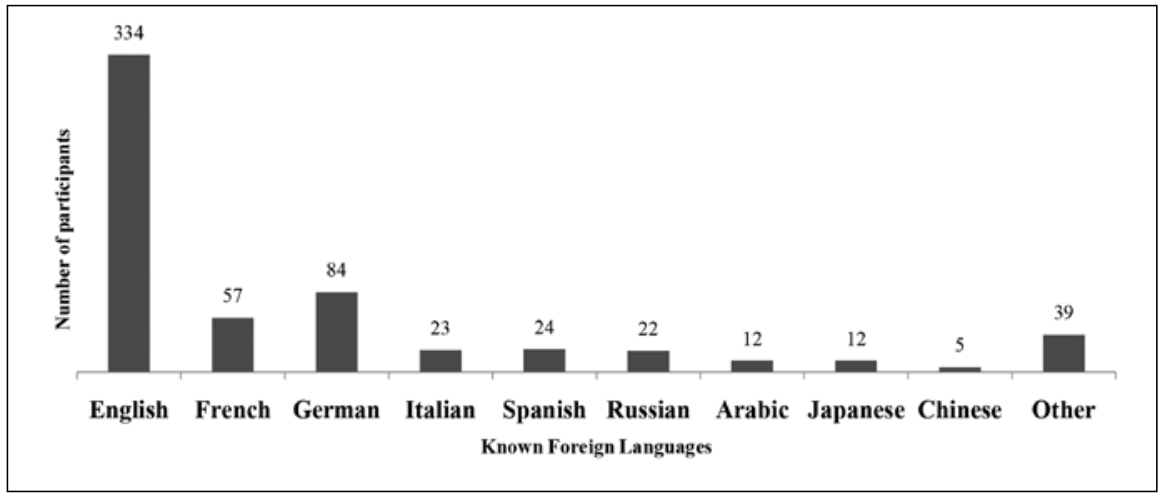

The statements which took place in the questionnaire were as follows:

1. Some languages are harder to learn.

2. Attitude plays a major role in language learning.

3. For people who are beyond the age of 45 , it is difficult to learn a new language.

4. It is easier to learn a new language for a person who has already learnt one.

5. For people who are beyond the age of 45 , learning a new language prevents dementia and Alzheimer's disease.

6. For people who are beyond the age of 45 , it is easier to learn a language which is typologically closer to their first language.

7. People who are beyond the age of 45 , make comparisons of their first language's grammar with the new language's grammar.

8. It is difficult for people who are beyond the age of 45 , to get to advanced levels in the newly learnt language.

Other than these eight statements, there were three questions. The first two were multiple choice responses where the last one was a yes/no/not sure optioned question. The questions were as follows:

1. For people who are beyond the age of 45 , which of the following skill/s is/are more difficult to achieve in language learning?

2. Which of the following would be the motive/s for people who are beyond the age of 45 to start learning a new language?

3. Would you like to start learning a new language? 
There were also demographic questions about the participants' age, gender, educational background and the languages they know.

\section{Results}

The study's first question was about the beliefs of people from different ages concerning language learning and adult language. In order to reach an answer to this question, responses to the statements and answers to the questions were analysed (see Table 2).

Table 2: Numbers of different age groups' responses to all statements and questions.

\begin{tabular}{|l|l|l|l|l|l|}
\hline & I agree & I disagree & I'm not sure & Sd & Responses \\
\hline Statement 1 & 322 & 38 & 16 & 139.35 & 376 \\
\hline Statement 2 & 345 & 14 & 17 & 155.33 & 376 \\
\hline Statement 3 & 158 & 139 & 78 & 34.13 & 375 \\
\hline Statement 4 & 332 & 20 & 23 & 146.38 & 375 \\
\hline Statement 5 & 257 & 23 & 95 & 97.86 & 375 \\
\hline Statement 6 & 237 & 64 & 68 & 80.63 & 369 \\
\hline Statement 7 & 276 & 57 & 47 & 80.63 & 378 \\
\hline Statement 8 & 138 & 152 & 85 & 28.86 & 375 \\
\hline
\end{tabular}

\begin{tabular}{|c|c|c|c|c|c|c|c|c|}
\hline \multirow{2}{*}{ Question 1} & \multirow{2}{*}{$\begin{array}{l}\text { Vocabulary } \\
201\end{array}$} & \multirow{2}{*}{$\begin{array}{l}\text { Pronunciation } \\
97 \\
\end{array}$} & \multirow{2}{*}{$\begin{array}{l}\text { Grammar } \\
104\end{array}$} & \multicolumn{3}{|c|}{ Learning a new writing system } & \multicolumn{2}{|c|}{ Responses } \\
\hline & & & & \multicolumn{3}{|l|}{97} & \multicolumn{2}{|l|}{377} \\
\hline \multirow[t]{2}{*}{ Question 2} & $\begin{array}{l}\text { Using } \\
\text { Internet }\end{array}$ & Hobby & Work & $\begin{array}{l}\text { Touristic } \\
\text { purposes }\end{array}$ & $\begin{array}{l}\text { Reading } \\
\text { literature }\end{array}$ & $\begin{array}{l}\text { Watching } \\
\text { movies }\end{array}$ & $\begin{array}{l}\text { Mental } \\
\text { activity }\end{array}$ & Responses \\
\hline & 109 & 188 & 184 & 215 & 70 & 59 & 183 & 377 \\
\hline \multirow[t]{2}{*}{ Question 3} & I do & I don't & $\begin{array}{l}\text { I'm not } \\
\text { sure }\end{array}$ & $\mathrm{Sd}$ & Responses & & & \\
\hline & 253 & 68 & 56 & 90.17 & 377 & & & \\
\hline
\end{tabular}

Of the 376 participants who responded to the first statement, $86 \%$ agreed that, some languages are harder to learn. $10 \%$ of the respondents disagreed and only $4 \%$ were not sure. As the majority of respondents believed that some languages are harder to learn, there was also a consensus between the different age groups (see Figure 5). The respondents of 66-70-year-olds group had the highest percentage (27\%) of disapproval in this statement. 
Figure 5: Percentages of different age groups' responses to first statement.

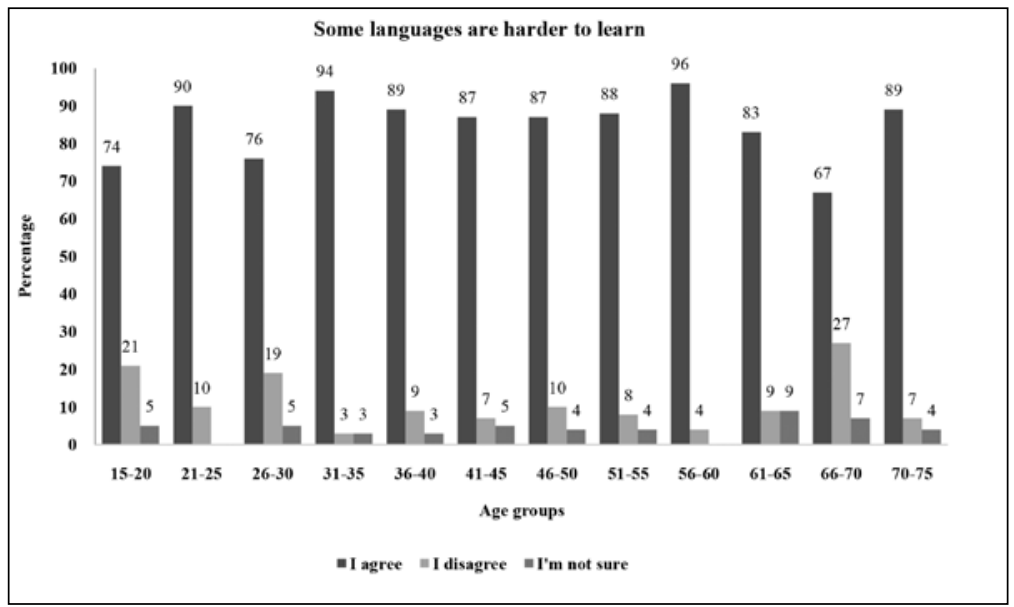

For the second statement, again 376 participants responded and the vast majority (92\%) of them agreed that attitude plays a major role in language learning. 3\% of respondents disagreed where $5 \%$ of respondents were not sure about this statement. There was a consensus of agreement with this statement between all different age groups and all participants of 66-70-year-olds group agreed that attitude plays a major role in language learning (See Figure 6).

Figure 6: Percentages of different age groups' responses to second statement.

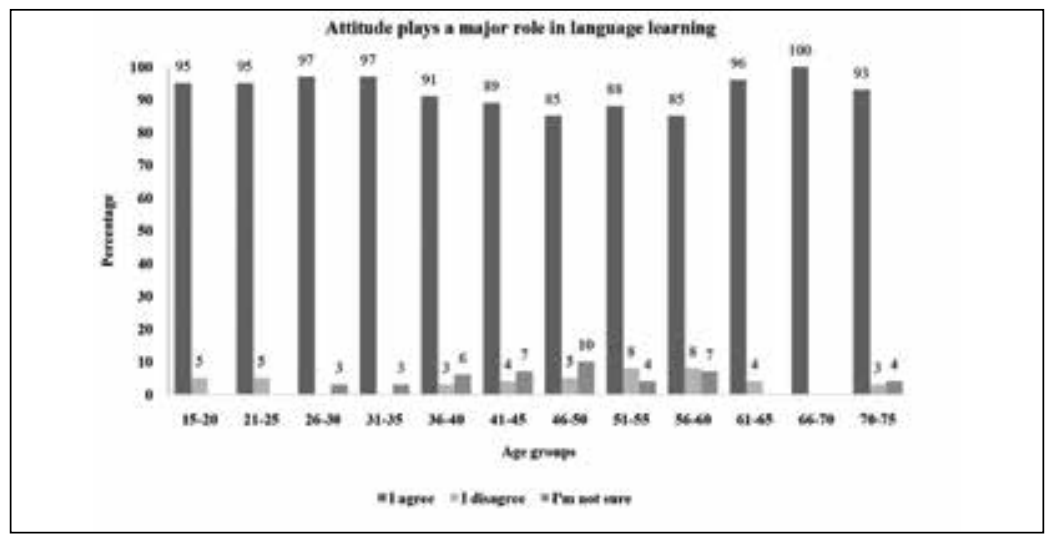

The third statement was about the difficulty of learning a new language for people who are beyond the age of 45 . In this statement, number of agreement and disagreement were very close. $42 \%$ of respondents agreed and $37 \%$ of respondents disagreed that, it would be 
difficult to learn a new language after the age of 45 . Besides, $21 \%$ of respondents of the total 375 responses were not sure about this statement. When analysed by different age groups, it can be observed that, only with the participants of 61-65-year-olds group, more than half of the respondents think that it is not difficult to learn a new language after the age of 45 . (See Figure 7).

Figure 7: Percentages of different age groups' responses to third statement.

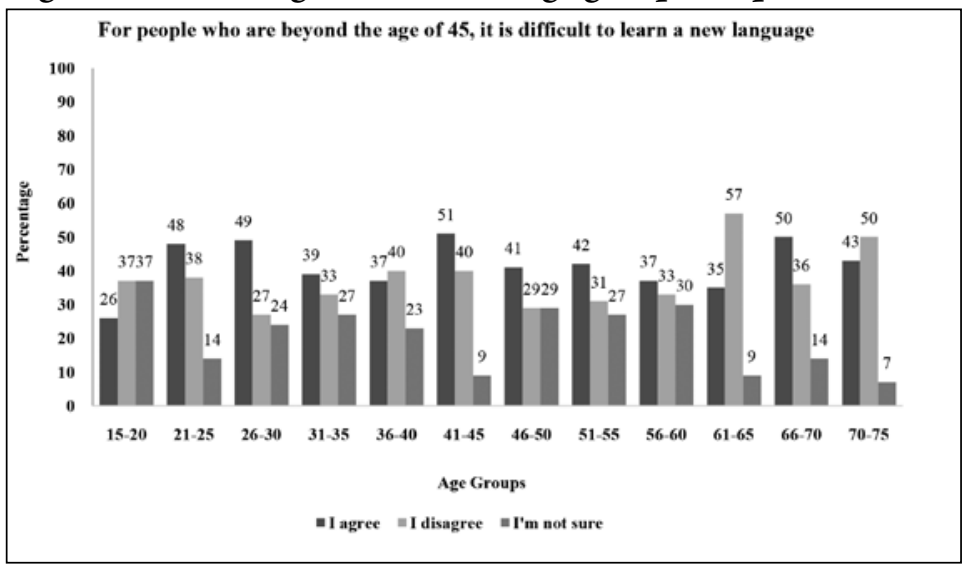

The majority ( $89 \%$ ) of 375 respondents agreed with the statement which says it is easier to learn a new language for a person who has already learnt one. Only a small fraction of participants disagreed (5\%) and some were indecisive (6\%).

Figure 8: Percentages of different age groups' responses to fourth statement.

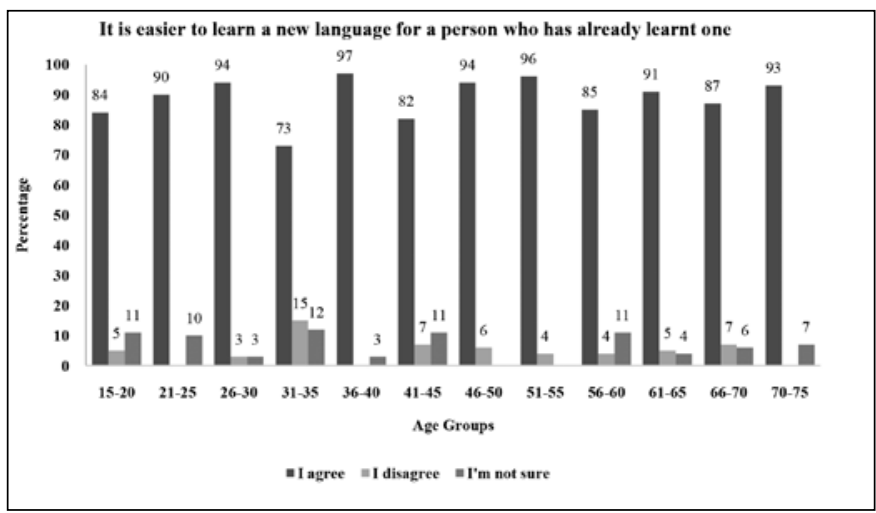


Figure 8 shows that the majority of all different age groups believe that, it is easier to learn a new language after learning at least one foreign language. The smallest agreement percentage (73\%) was the result of 31-35-year-olds group.

A very popular discussion is whether learning a new language prevents dementia and Alzheimer's disease or not. The fifth statement of the questionnaire asked the participants' thoughts about this subject and $69 \%$ of 375 of respondents agreed that, for people who are beyond the age of 45, learning a new language prevents dementia and Alzheimer's disease. Moreover, with this statement, $25 \%$ of respondent were not sure and only $6 \%$ disagreed. The number of not sure responses were higher than the rest of the statements. As seen in Figure 9, especially the respondents who are 60 and up agree a great deal with this idea.

\section{Figure 9: Percentages of different age groups' responses to fifth statement.}

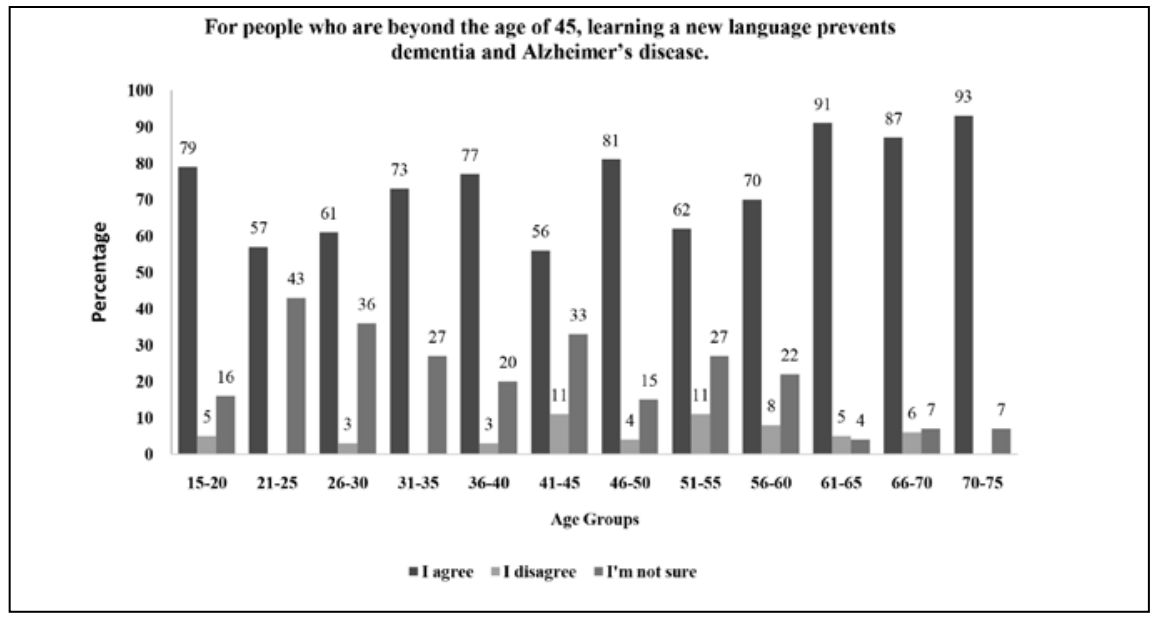

The sixth statement was telling that, it is easier to learn a language which is typologically closer to one's first language especially for people who are beyond the age of 45 . More than half $(64 \%)$ of 369 respondents agreed but $18 \%$ of respondents disagreed and $18 \%$ of them were not sure. The distribution of responses according to different age groups can be seen in Figure 10. The respondents of 51-55-year-olds group had the highest percentage (32\%) of disapproval. 
Figure 10: Percentages of different age groups' responses to sixth statement.

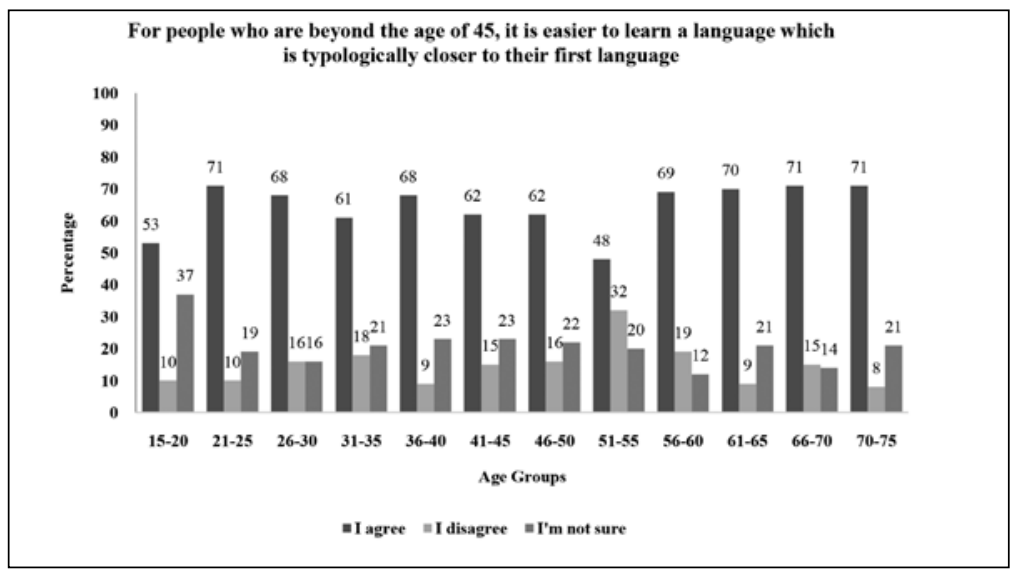

The seventh statement proposed that, people who are beyond the age of 45 , make comparisons of their first language's grammar with the new language's grammar. Most of the 378 respondents $(73 \%)$ agreed while $15 \%$ disagreed and $12 \%$ were not sure. While the vast majority (89\%) of 56-60-year-olds group agreed with this statement; 66-70-year-olds group had the highest disagreement percentage (27\%) in all of the different age groups (see Figure 11).

Figure 11: Percentages of different age groups' responses to seventh statement.

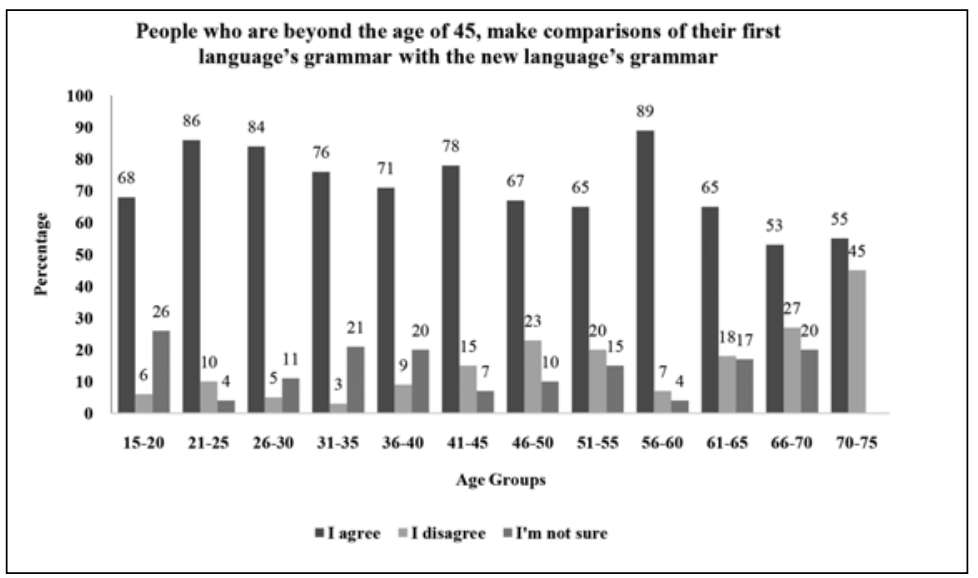

The eighth statement asked the participants whether they agree or not. $41 \%$ of the 375 respondents disagreed with the idea that it is difficult for elder people to get to advanced levels in the newly learnt language. On the other hand, 36\% agreed and $23 \%$ were not sure. 
Although it was not very distinct, disagreement with this statement is more obvious than the other statements. The respondents of 61-65 and 70-75-year-olds groups show 57\% of agreement and the respondents 15-20-year-olds group indicated a very low percent (16\%) of approval while all other age groups either disagreed or were not sure (see Figure 12).

Figure 12: Percentages of different age groups' responses to eighth statement.

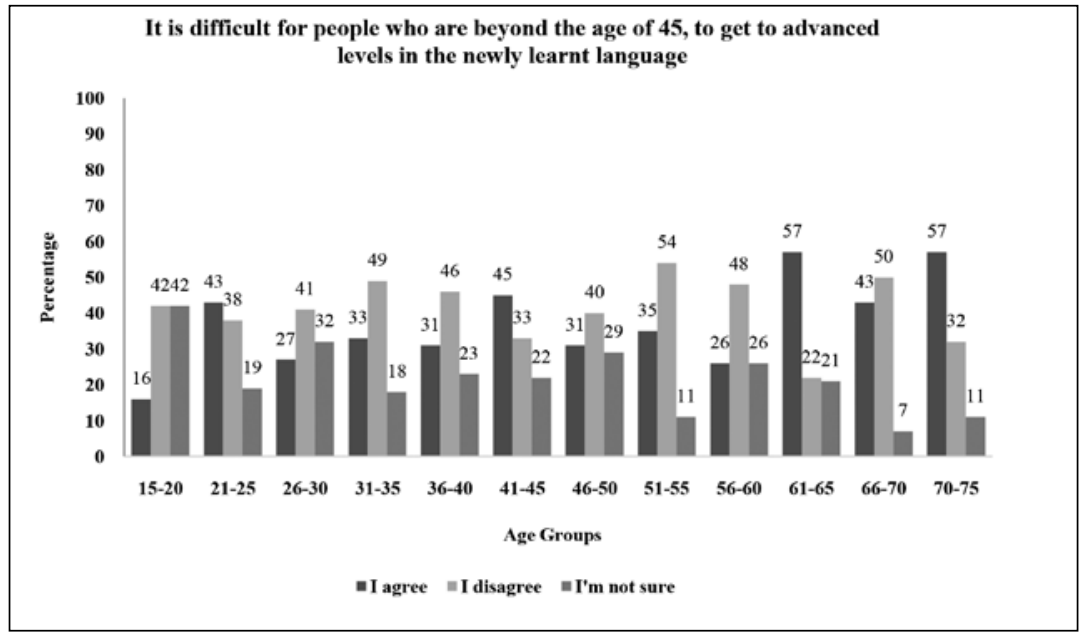

As mentioned above, there were also three questions in the questionnaire. The respondents had the chance to choose more than one alternative for the first two questions. The first question was about the respondents' opinions about the difficulty of achieving skills for people who are beyond the age of 45 , in language learning.

\section{Figure 13: Percentages of different age groups' answers to first question.}

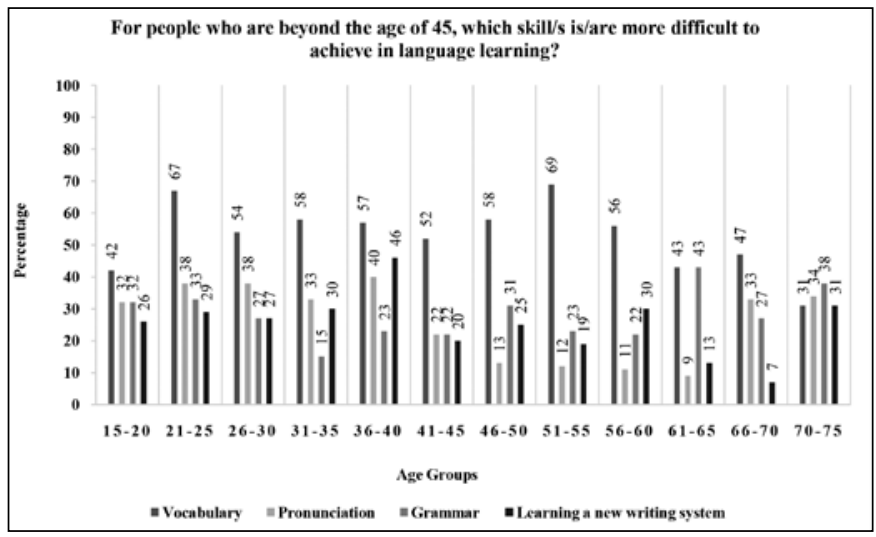


The alternatives were vocabulary, pronunciation, grammar and learning a new writing system. 377 participants answered this question and 53\% of them said that, vocabulary seems to be the most difficult to achieve. The second most difficult field is grammar with $28 \%$, pronunciation and learning a new writing system, both had $26 \%$ of the responses. Distribution of the answers to this question according to different age groups can be seen in Figure 13.

The second question was about the motives of people who are beyond the age of 45 for starting to learn a new language. The alternatives were using internet, hobby, work, touristic purposes, reading literature, watching movies and mental activity. Of the 377 participants who answered this question, $57 \%$ chose touristic purposes which was followed by hobby (50\%), work (49\%) and mental activity (49\%). Using internet (29\%), reading literature (19\%) and watching movies (16\%) were chosen by a less amount of participants (see Figure 14). While learning for touristic purposes was the favourite choice of most of the age groups, work was the favourite choice of 70-75-year-olds group (62\%).

\section{Figure 14: Percentages of different age groups' answers to second question.}

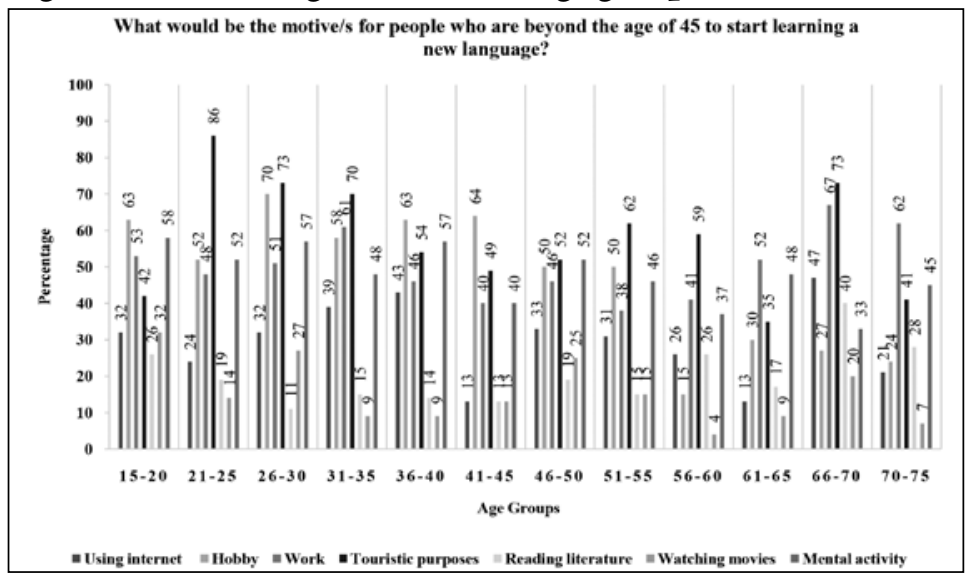

The last question of the questionnaire was whether the participants would like to start learning a new foreign language or not. This question had yes/no/not sure options. 377 participants answered this question and $67 \%$ said that they would like to start learning a new language. $18 \%$ said they wouldn't and $15 \%$ said they were not sure whether they would like it or not. All of the 21-25-year-olds group respondents indicated that, they would like to start learning a new language but the participants of groups which are 61 years and up were not so enthusiastic about it (see Figure 15). 
Figure 15: Percentages of different age groups' answers to third question.

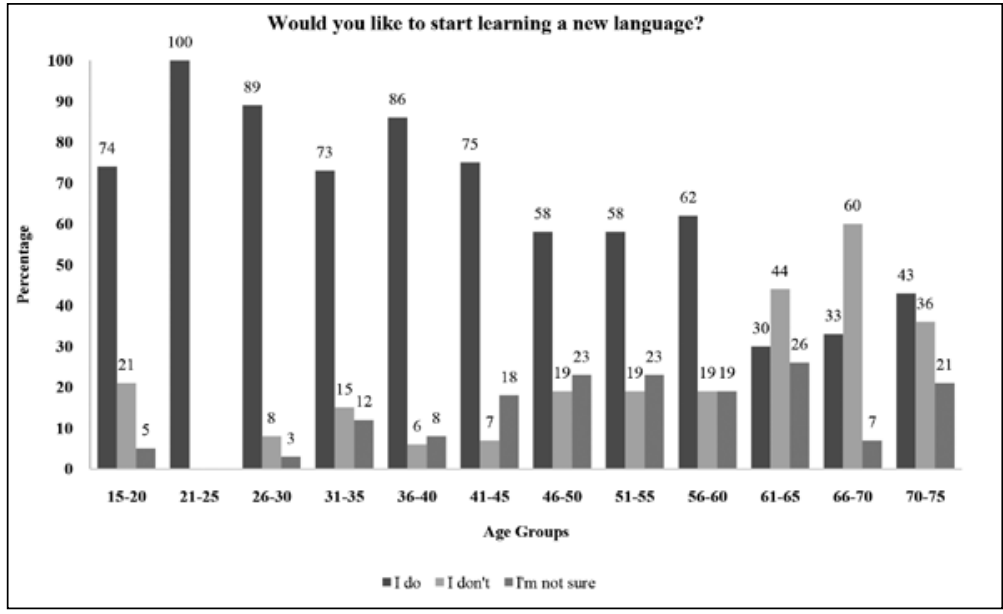

\section{Discussion}

In today's world and lifestyle, people are living quite fast which leads a celerity and impatient state-of-mind. It gets harder and harder to find volunteers for academic studies especially if it requires time consuming questionnaires. People do not want to spare time for paper and pen kind of surveys. But on their idle times like while waiting for something or on the way home most of them check their social media accounts or search the web. From this point of view, an online questionnaire was used in this study. But although more participants can be found this way, the number of questions in the questionnaire was still crucial because people don't like to deal with anything that lasts long. That is why, in the questionnaire of this study, only 15 questions ( 8 statements, 3 multiple choice questions and 4 demographic questions) were included. While preparing the instrument, the demographic questions were especially asked at the end, thinking that respondents do not like to start every questionnaire by answering the questions about themselves. But, all these facts withheld the researcher from asking detailed questions and more statements. Still, this study may be a starting point of a series of researches concerning different beliefs about language learning. The findings revealed that participants of different ages find some languages harder to learn and believe attitude plays a major role in language learning. As mentioned before, Turkish people have strict beliefs about languages. For example, it is a common thought that French has a very difficult grammar and Italian has a very harmonic pronunciation, and so forth. The results are consistent with this general thinking. Only the youngest respondents (15-20-year-olds) and 66-70-year-olds group's respondents had slightly more disagreement responses ( $21 \%$ and $27 \%$ respectively) than the other age groups. This may be interpreted 
with being experienced in learning or not. Young people may not be experienced enough to differentiate between the languages whereas elder ones may have the experience to realise that languages can't be labelled as difficult or easy.

All respondents agreed that, it is easier to learn a new language for a person who has already learnt one and they share similar beliefs about learning a new language preventing dementia and Alzheimer's disease. In Turkey, there is a common idea that learning new languages, specifically the ones which have a different writing system, may prevent these diseases. People, especially the ones who have an Alzheimer's disease patient in their family, try to solve cross word puzzles every day, learn handicraft, and memorize riddles and so on.

As previously stated, explicit grammar teaching is still seen as fundamental in language teaching by a majority of population, so when asked about typological similarity and making comparisons between the first language and the new one, most of the respondents agreed with the statements. Here it must be mentioned that, in the original questionnaire, which was in Turkish, the term "typologically close" was not used. Instead it was expressed as a foreign language which is similar to one's mother tongue.

Concerning the beliefs about skills in language learning, all age groups except 70-75-yearolds, stated that vocabulary learning is the most difficult part of the process if the student is beyond the age of 45 . Most of the people believe that vocabulary should be memorised, and in adulthood it gets harder to memorise. This result may be rooted from these thoughts. On the other hand, respondents of 70-75-year-olds group think grammar is the most difficult part for the adult learner. This question was the one which showed more diversity between age groups than all the other statements. It may be concluded that, conception of difficulty changes according to different age groups.

When the motives of learning a new language after 45 years old are put into an order, learning for touristic purposes takes the first place. People in Turkey can usually find the opportunity to go abroad only after retirement, so they sometimes prefer to learn the language, at least some basic expressions, in order to have communication with the local people. In the second place comes hobby, which is followed by work and doing a mental activity. Using the internet and reading literature were not the favourite motives by any age group. The least chosen motive was watching movies. This may be because, in Turkey movies are mostly dubbed especially in television channels, and one can always find a dubbed version of the films in cinemas.

As for the second research question which was about the correlation between the beliefs and language course enrolment percentages it can be said that they are not coherent. The 
-

results show that people from different ages think in favour of learning a new language after 45 years old, but the enrolment numbers show the opposite. This result reminds a saying: "Easier said than done!"

The low enrolment rates may depend on at least two major reasons, especially in Turkey. First reason is economic. Language institutes' fees vary, but the cheapest course (they last usually two months per course) is approximately $1 / 4$ of a monthly retirement pension. The second reason is accessibility. Not all of the cities have language institutions and, in many of the small cities there are language courses in which only English is being thought. Once again mainly for the economic reasons, many people choose to live in small cities when they get retired. Also, according to Turkish cultural and societal beliefs, older people should be less mobile, they should be served and looked after, live a more isolated life in which they should act like advisers not students.

The results of this study show that, people's beliefs about late language learners are changing despite the strict cultural judgements about aging. One must keep in mind that, there is no decline in the ability to learn as people get older. Minor problems like hearing and altered eye sight, should not be overrated. Also it shouldn't be forgotten that, the older adult brain is still plastic and initiating language learning will improve language related functions as well as cognitive functions in older adults. The adult learners need to take more control over their lives.

\section{Final remarks}

As discussed earlier, using an online questionnaire is a very rapid process. It reaches to so many participants in such a short time, but it also has some disadvantages. The instrument used in this study consisted of a little amount of questions/statements with the presumption that, participants would get bored and leave the questionnaire unfinished. Another restriction was the profile of the participants. Kwik Survey, uses Facebook accounts as the medium of responding so the researcher has to send the questionnaire to her own list of associates first and then ask them to pass the invitation to the people in their own list. This brings the problem of not reaching to a heterogeneous group of participants. In this study for example, the participants were all well-educated people who knew a couple of different foreign languages, they were mostly living in big cities or even abroad. The participants' occupations were not asked but one can assume that they were all middle and upper class citizens. Surely another study with a different group of participants, from different socioeconomic backgrounds, should present a different result. 


\section{References}

BaileyJr, D.B., Bruer,J.T., Symons, F.J. \& Lichtman, J.W. (2001) Critical Thinking about Critical Periods. A Series from the National Center for Early Development and Learning. Brookes Publishing.

Brookfield, S. (1995) Adult learning: An overview. International Encyclopaedia of Education 10, 375 380.

Brown, A.L., Kane, M.J.\& Long, C. (1989) Analogical transfer in young children: Analogies as tools for communication and exposition. Applied Cognitive Psychology 3, 275-293.

Chen, H.C. \& Leung, Y.S. (1989) Patterns of lexical processing in a nonnative language. Journal of Experimental Psychology: Learning, Memory, and Cognition 15(2), 316-325.

Cohen, G.D. (2003) Aging and Mental Health. The Merck Manual of Geriatrics. Retrieved from http:// www.merck.com/pubs/mm_geriatrics/sec4/ch32.htm

Dewey, J. (1986) Experience and education. The Educational Forum 50 (3), 241-252.

Epstein, S.D., Flynn, S.\& Martohardjono, G. (1996) Second language acquisition: Theoretical and experimental issues in contemporary research. Behavioral and Brain Sciences 19 (04), 677-714.

Flege, J.E., Yeni-Komshian, G.H.\&Liu, S. (1999) Age constraints on second-language acquisition. Journal of Memory and Language 41(1), 78-104.

Gibbons, L.A.R. (2003) Older Adults Learning Online Technologies: A Qualitative Case Study of the Experience and the Process. Virginia Polytechnic Institute and State University

Hakuta, K (2001) A critical period for second language acquisition. Critical Thinking about Critical Periods, 193-205.

http://www.indexmundi.com/turkey/age_structure.html

Ioup, G., Boustagui, E., Tigi, M.E.\& Moselle, M. (1994) Reexamining the critical period hypothesis: A case study of successful adult SLA in a naturalistic environment. Studies in Second Language Acquisition 16, 73-98.

Johnson, J.S. (1992) Critical period effects in second language acquisition: The effect of written versus auditory materials in the assessment of grammatical competence. Language Learning 42, 217-248.

Johnson, J.S.\& Newport, E.L. (1989) Critical period effects in second language learning: The influence of maturational state on the acquisition of English as a second language. Cognitive Psychology 21, 60-99.

Johnson, J.S.\& Newport, E.L. (1991) Critical period effects on universal properties of language: The status of subjacency in the acquisition of a second language. Cognition 39, 215-258.

Kemper, S. (1992) Language and aging. In F.I.M. Craik and T.A. Salthouse (eds), The Handbook of Aging and Cognition (pp. 213-270). Hillsdale, NJ: Erlbaum.

Knowles, M.S. (1968) Andragogy Not Pedagogy, Adult Leadership 16 (10), 350-386. 
Dill Dergisi o Saye: 1681 o Ocak-Hagiran 2017

Knowles, M. S., Holton III, E. F.\& Swanson, R. A. (2014). The Adult Learner: The Definitive Classic in Adult Education and Human Resource Development. Routledge.

Krashen, S. (1973) Lateralization, language learning, and the critical period. Language Learning 23, 63-74.

Laslett, P. (1989) A Fresh Map of Life: The Emergence of the Third Age. Weidenfeld and Nicolson, London.

Lenneberg, E.H. (1967) Biological Foundations of Language. New York: Wiley.

Marinova-Todd, S.H., Marshall, D.B. \& Snow, C.E. (2000) Three misconceptions about age and L2 learning. TESOL Quarterly 34 (1), 9-34.

Monstad, S.J. (2006) Gerontology and ICT. Document prepared for the 2. ICT50+ seminar, Castellon, Spain. Retrieved from www.ict50plus.uji.es/eng/results/lsn-gerontology50plus.pdf

Oyama, S. (1976) A sensitive period for the acquisition of a nonnative phonological system. Journal of Psycholinguistic Research 5, 261-283.

Patkowski, M. (1980) The sensitive period for the acquisition of syntax in a second language. Language Learning 30, 449-472.

Patkowski, M. (1994) The critical age hypothesis and interlanguage phonology. In M. Yavas (ed.), First and Second Language Phonology (pp. 205-221). San Diego: Singular Publishing Group.

Paradis, M. (2004) A Neurolinguistic Theory of Bilingualism. Amsterdam: John Benjamins.

Penfield, W. \& Roberts, L. (1959) Speech and Brain Mechanisms. Princeton, NJ: Princeton University Press.

Pinker, S. (1994) The Language Instinct. New York: W. Morrow and Co.

Schleppegrell, M. (1987) The Older Language Learner. Retrieved from ericae.net/edo/ed287313. htm.

Singleton, D.M. \& Lengyel, Z. (eds) (1995) The Age Factor in Second Language Acquisition: A Critical Look at the Critical Period Hypothesis. Multilingual Matters.

Skehan, P. (1998) A Cognitive Approach to Language Learning. Oxford: Oxford University Press.

Withnall, A. (2002) Three decades of educational gerontology: Achievements and challenges. Education and Ageing 17 (1), 87-102.

Zare, H., Gaskin, D.J. \& Anderson, G. (2015) Variations in life expectancy in Organization for Economic Co-operation and Development countries-1985-2010. Scandinavian Journal of Public Health 43, 786-795. 
